while teaching navigation, after retiring from service afloat, he acquired a B.Sc degree in geography and the inspiration for research from his professor, E. G. R. Taylor. He was thus admirably equipped, technically as well as by inclination and training, for the historical research in almost all aspects of navigation with which he has enriched navigational literature. And it was, in due course, acknowledged by the award by UWIST, of an M.Sc and a Ph.D. Even though his main technical work was in the field of magnetism, he shared my own interests in all aspects of astronomical navigation; his doctorate was for his outstanding thesis 'A History of Nautical Astronomical Tables' for which I have a specially high regard. He frequently called my attention to long forgotten suggestions and comments that he came across during his researches.

Personally, he was a truly delightful man. Physically rather short, he was a:ways inpeccably neat; my wife also says that he was our tidiest house-guest. His extensive knowledge was freely at the disposal of numerous correspondents from many countries, and he must have written, in long hand, hundreds of helpful letters; he, and his writings, were thus appreciated abroad as much as in this country. There have already been expressions of astonished dismay at his sudden death from his friends and colleagues abroad - particularly from the USA, which he visited for several weeks in September and October. They share their grief with those who saw Charles Cotter in such ebullient mood at the Institute's reception on 15 October.

He was born on 21 January 1919 in the small town of Hirwaun near Aberdare, and spent m.uch of his life in Wales, finally retiring to Aberaeron in a house overlooking the sea. He leaves a widow, Lilian, and four sons.

$$
\text { D. H. S. }
$$

\title{
Richard Brakell Richardson
}

R. B. RICHARDSON, known perhaps inevitably as Dickie to his wide circle of friends, a Fellow and past Treasurer of the Institute, died suddenly but peacefully in Zimbabwe on 30 October 1981. He came from a long line of seafarers and his son Simon is currently serving as a Master at sea; both these facts gave him great pride. After Pangbourne, Dickie spent 22 years at sea as an executive officer in the Royal Navy, qualifying as a specialist in communications in 1942. After the war he became first of all Assistant Harbourmaster and then Harbourmaster of the Port of London and he was largely responsible for the introduction of the Thames Navigation Service. Latterly he held a number of navigational consultancies and worked part time at the Institute helping the Director. He was a familiar figure at IMCO where he so often represented the International Association of Institutes of Navigation, and at navigational conferences both here and abroad where he frequently represented the Institute.

Dickie Richardson totally identified with the objects of the Institute and he saw navigation in terms of philosophy rather than as a purely technological 
matter. His overriding interest, which never quite bore fruit, was in the idea of an international convention for navigation at sea, such as prevails in the air. This he believed could be the most enduring contribution of the Institutes to better navigation. His own contributions to navigation were not inconsiderable, for he had both a clear mind and a natural inventiveness. He was Chairman of the Institute Committee which compiled the standard marine vocabulary adopted by IMCO; with Brian Calvert he designed and introduced the ROFAC charts which present to the mariner so much information formerly contained in books; and more recently he invented the Traverse Light, still in its experimental stage, an ingenious device which enables the seaman to navigate an approach channel at a predetermined speed.

M. W. R.

\section{Navigational Terms}

In the September 198 I number of the Journal $(34,484)$ a brief account was given of the navigational terms approved by the Council of the Nautical Institute. It was stated that this Institute, which was very largely responsible for the British Standards Glossary of Navigation Terms (BS 4883 : 1973), was looking into whether the new terms proposed called for any revision of the British Standards publication.

Under the authority of the Council a small group which included those who had drafted $\mathrm{BS}_{488} 3$ discussed the Nautical Institute's terms and concluded that although $\mathrm{BS}_{4} 88_{3}$ could be improved in a number of ways by a rearrangement of some of the entries into different sections, and perhaps by several additions, no alterations seemed called for specifically because of the Nautical Institute terms.

The group felt that some of the terms proposed by the Nautical Institute were based on questionable assumptions (such as that track may be defined as a vector) or differ from their dictionary meanings, which could cause legal problems. A number of comments on the proposed terms have been put to the Nautical Institute. 